UDC 343.541

LBC 67.408.113

\title{
EVOLUTION OF THE RELEASE FROM CRIMINAL LIABILITY INSTITUTE AND THE PRESUMPTION OF INNOCENCE ${ }^{1}$
}

\author{
Lyubov V. Lobanova \\ Volgograd State University, Volgograd, Russian Federation
}

Introduction. The paper studies the problem of legitimacy of norms, regulating release from criminal liability and determining a procedural form of implementation of such release. Purpose of this investigation is to check out the norms regulating release from criminal liability as well as enshrining a procedural form of such release in the context of compliance with the principle of presumption of innocence. The investigation is intended to establish if it is necessary to keep that institute in the current legislation. Methods. The study is a multimethod research. The knowledge of different branches of legal science is used during the investigation. Results. It is shown that release from criminal liability is a constantly developing legal institute. It is proved that it is predetermined by the importance of this measure of criminal-legal nature for the solution of problems enshrined in clause 2 of the Criminal Code of the Russian Federation. The opinions of scientists, who suppose that the institute of release from criminal liability and rules designed to regulate its procedural form conflict with the principle of presumption of innocence, are analyzed. It has been found that the essence of release from criminal liability is deliverance of the person committed a crime from conviction for the commission of a crime. It is proved thereupon that the person can't be immune from criminal liability under sentence. The explanation for why a person doesn't plead guilty to a crime in case of the termination of criminal case (prosecution) on not rehabilitating grounds is offered. Conclusion. It is concluded that procedural rules, determining the order of release from criminal liability, fully conform to clause 49 of the Constitution of the Russian Federation. A conclusion is also made that there is a need to keep the institute corresponding with these rules. Field of application. The study is recommended for scientists and practitioners.

Key words: release from criminal liability, positive post-criminal behavior, presumption of innocence, termination of criminal case (prosecution) on not rehabilitating grounds, conviction for the offence.

УДК 343.541

ББК 67.408 .113

\section{РАЗВИТИЕ ИНСТИТУТА ОСВОБОЖДЕНИЯ ОТ УГОЛОВНОЙ ОТВЕТСТВЕННОСТИ И ПРЕЗУМПЦИЯ НЕВИНОВНОСТИ ${ }^{1}$}

\author{
Любовь Валентиновна Лобанова \\ Волгоградский государственный университет, г. Волгоград, Российская Федерация
}

\begin{abstract}
Введение: в статье освещается проблема легитимности норм, регламентирующих освобождение от уголовной ответственности и определяющих процессуальную форму осуществления такого освобождения. Цель: провести ревизию норм, регламентирующих освобождение от уголовной ответственности, а также закрепляющих процессуальную форму такого освобождения, с точки зрения их соответствия конституцион-

ному положению о презумпции невиновности, определить необходимость сохранения соответствующего ㄱ института в современном законодательстве. Методы: исследование носит комплексный характер. При его ضे осуществлении используются знания из различных областей юридической науки. Результаты: показано, что освобождение от уголовной ответственности является постоянно развивающимся правовым образованием. Обосновано, что это предопределено значимостью данной меры уголовно-правового характера для решения задач, закрепленных в ст. 2 УК РФ. Проанализирована позиция ученых, считающих институт освобождения от уголовной ответственности и нормы, призванные регламентировать его процессуальную форму, (0) противоречащими презумпции невиновности. Выяснено, что сущностью освобождения от уголовной от-
\end{abstract}


ветственности является избавление лица, совершившего преступление, от признания данного субъекта виновным в совершении преступления, и на этой основе доказано, что лицо не может быть освобождено от уголовной ответственности по обвинительному приговору суда. Дано объяснение тому, почему лицо не признается виновным в совершении преступления в случае прекращения в отношении его уголовного дела (уголовного преследования) по нереабилитирующим основаниям. Сделаны выводы о полном соответствии действующих процессуальных норм, определяющих порядок освобождения от уголовной ответственности, ст. 49 Конституции РФ, и о необходимости сохранения корреспондирующего данным нормам уголовноправового института. Область применения: рекомендуется для научных и практических работников.

Ключевые слова: освобождение от уголовной ответственности, позитивное посткриминальное поведение, презумпция невиновности, прекращение уголовного дела (преследования) по нереабилитирующим основаниям, признание лица виновным в совершении преступления.

\section{Введение}

В российском уголовном праве одним из самых динамично развивающихся нормативных образований является институт освобождения от уголовной ответственности. Наиболее активно конструируются нормы, с помощью которых осуществляется стимулирование лица, совершившего преступление, к позитивному посткриминальному поведению. Так, с момента вступления в силу действующего Уголовного кодекса России число статей его Общей части, закрепляющих подобные основания, удвоилось (ст. $75,76,76^{1}, 76^{2}$ ). А в Особенной части насчитывается уже 37 примечаний, содержащих соответствующие поощрительные нормы.

Однако обновление рассматриваемого уголовно-правового института, как правило, вызывает упреки в адрес законодателя. Периодически звучат голоса о противоречии соответствующих поощрительных норм принципам уголовного либо уголовно-процессуального законодательства.

\section{Основная идея освобождения от уголовной ответственности и ее процессуальное воплощение}

В обоснование нелегитимности института освобождения от уголовной ответственности приводится один и тот же базовый довод. «Освобождение от уголовной ответственности, - пишет, например, С.В. Проценко, - по какому бы основанию оно ни производилось, означает признание лица виновным» [6, с. 23]. Это утверждали еще представители советской науки уголовного права [2, с. 216; и др.].
Сходством обладает и ход дальнейших размышлений современных авторов и исследователей прошлого столетия. Подчеркивается важность положений, закрепленных в ст. 160 Конституции СССР 1977 г. и ст. 49 Конституции РФ, об исключительном праве суда на признание лица виновным в совершении преступления и применение к нему уголовного наказания, причем не иначе как в установленном законом порядке и по приговору. А поскольку согласно закону освобождение от уголовной ответственности осуществляется и другими органами, выражающими соответствующее решение в актах о прекращении уголовного дела (преследования) либо об отказе в его возбуждении, то с учетом озвученного выше теоретического постулата делается вывод об антиконституционности института освобождения от уголовной ответственности, о недопустимости дальнейшего его существования в неизменном виде. Некоторыми учеными предлагается ограничить круг органов, уполномоченных на подобное избавление лица, совершившего преступление, от уголовно-правовых обременений, исключительно судебными инстанциями [3, с. 327-331; 4, с. $118-$ 119; и др.]. Автор считает реализацию данного предложения нецелесообразной.

Во-первых, институт освобождения от уголовной ответственности нужен государству для решения важных задач. Благодаря большему объему уголовно-правового поощрения он более эффективен как инструмент стимулирования лиц, совершивших преступление, к позитивному посткриминальному поведению, чем институт освобождения от наказания, и достаточно гибок для того, чтобы к каждому случаю, требующему уголов- 


\section{ПРОТИВОДЕЙСТВИЕ ПРЕСТУПНОСТИ}

но-правовой оценки, компетентные органы смогли подойти неформально, по-человечески, но при этом не нарушая закон. Освобождение от уголовной ответственности необходимо и для того, чтобы создавать условия для концентрации ресурсов и усилий государства на противодействие наиболее опасным преступлениям и при этом избежать необоснованной декриминализации деяний, представляющих опасность для существующих общественных отношений. При продуманной регламентации оснований и порядка осуществления такого рода освобождения, при должной реализации соответствующих норм на практике рассматриваемый институт может обладать немалым профилактическим потенциалом.

Во-вторых, в той процессуальной форме, которой предлагается заменить существующую, институт освобождения от уголовной ответственности не может быть реализован, поскольку она противоречит его сути.

Вот как видится перспектива изменения процессуальной формы освобождения от уголовной ответственности одному из инициаторов рассматриваемой рекомендации. «А суд, в силу предоставленных ему полномочий, - пишет А.П. Кругликов, - может при наличии оснований своим приговором признать лицо виновным в совершении преступления, о котором идет речь в ст. 25 , $28,28^{1}$ УК РФ, и этим же приговором освободить его от уголовной ответственности в случаях, указанных в соответствующих статьях УК РФ» [3, с. 331]. Хочется, однако, спросить: а в чем же будет заключаться тогда освобождение от уголовной ответственности? Ведь по замыслу законодателя таковое не тождественно освобождению от наказания (глава 11 УК РФ). Принимая во внимание разницу между этими двумя видами уменьшения объема ответственности, мы должны, как призывал в свое время М.Л. Якуб, отказаться от мысли, будто лицо, освобождаемое от уголовной ответственности, находится в положении признанного виновным в совершении преступления, поскольку именно в этом заключается «идея института освобождения от уголовной ответственности» [7, с. 23].
Право государства на признание лица виновным в совершении преступления и на отказ от такого признания. Делегирование полномочий

Признание лица виновным в совершении преступления не может рассматриваться только как какое-то особое процессуальное полномочие. По своей сути оно является составной частью правового статуса государства, чьи законы нарушены совершением преступления. Последнее выступает юридическим фактом, порождающим уголовно-правовое отношение. В рамках данного правоотношения государству также принадлежит право на наказание преступника, с назначением которого УК РФ связывает развитие судимости (ч. 1, 3 ст. 86 УК РФ). Реализации указанных полномочий корреспондирует и реализация уголовной ответственности в отношении второго субъекта уголовно-правового отношения. Таковая заключается в реальном претерпевании виновным тех юридически неблагоприятных последствий своего преступного деяния, которые предопределены осуществлением указанных полномочий данного властного субъекта уголовно-правового отношения - он [виновный] становится осужденным и в большинстве случаев подвергается наказанию, приобретая статус судимого лица.

Но каждый суверен всегда располагает еще одной возможностью. Он может отказаться от осуществления своих прав. Властный субъект уголовно-правового отношения не является исключением. Он компетентен как отказаться от реализации обоих своих прав и тем самым от реализации уголовной ответственности в целом, так и ограничиться официальным осуждением преступника, признанием его виновным в совершении преступления, освободив от наказания. В последнем случае уголовная ответственность все равно будет реализована. Отсюда, на наш взгляд, может быть сделан лишь один вывод, касающийся главного в освобождении от уголовной ответственности. Такое освобождение есть «избавление лица от признания его от имени государства виновным в совершении преступления или, что одно и то же, от государственного, официального осуждения за преступление» (ч. 2 ст. 77, ст. 308 УПК РФ) [1, с. 79]. 
Не следует также забывать, что государство как особого рода организация всегда действует через свои органы. Как суверен, государство вправе делегировать свои полномочия любому своему органу. Оно же [государство] определяет и порядок осуществления делегированных прав, связывая и себя, и свой орган законом.

Право на признание лица виновным в совершении преступления согласно ст. 49 Конституции РФ в России делегировано исключительно суду. В соответствии с данной статьей указанный орган может осуществить это право в установленном законом порядке, предполагающем не только вынесение, но и вступление в силу обвинительного приговора. Но из ст. 49 основного закона вовсе не вытекает, что государство делегировало только суду свое другое полномочие - право отказаться от возложения на гражданина соответствующего уголовно-правового обременения и что процессуальная форма такого полномочия должна быть абсолютно идентичной той, которая предназначена для признания лица виновным в совершении преступления. Напротив, разница в указанных полномочиях предопределяет временные рамки для реализации обоих прав. Претворение в жизнь одного из них исключает осуществление другого. А следовательно, законодатель не только не был должен, но и по сути не мог облечь освобождение от уголовной ответственности в ту же, без каких-либо изъятий, процессуальную форму, в рамках которой такая ответственность реализуется.

\section{Юридическая сила актов о прекращении уголовного дела}

На наш взгляд, сопоставляя положения ст. 49 Конституции РФ с процессуальным законодательством, мы должны исходить из следующего. Поскольку право на опровержение презумпции невиновности предоставляется только суду и только в одном правоприменительном документе - обвинительном приговоре, всякое иное решение суда и какое бы то ни было решение иного органа, осуществляющего производство по делу, не способны эту презумпцию поколебать, ибо не заключают в себе признание лица виновным в совер- шении преступления. Это относится и к тем правоприменительным актам, в которых так или иначе констатируется факт совершения лицом преступления и обосновывается виновность данного субъекта, включая документы о прекращении уголовного дела (преследования) по нереабилитирующим основаниям. Юридическая сила этих документов и обвинительных приговоров не одинакова. Способность обвинительного приговора и постановления следователя о прекращении уголовного преследования служить процессуальным препятствием для продолжения производства по делу в отношении того же лица по тому же обвинению (п. 4 и 5 ч. 1 ст. 27 УПК РФ) еще не есть доказательство того, что уравнены и другие юридические последствия принятия подобных решений. В отличие от признания лица виновным в совершении преступления, находящего отражение во вступившем в законную силу обвинительном приговоре суда, установление факта совершения преступления и констатация виновности в нем конкретного лица, имеющие место в акте о прекращении уголовного дела (преследования), не могут иметь преюдициального значения. Высшие судебные органы нашей страны пытаются довести до правоприменителя как раз эту мысль, нацеливая его на правильное толкование такого понятия, как «впервые совершенное преступление».

Так, согласно абз. «д» п. 2 Постановления Пленума Верховного суда РФ «О применении судами законодательства, регламентирующего основания и порядок освобождения от уголовной ответственности» от 27 июля 2013 г. № 19 впервые совершившим преступление судам рекомендовано считать при реализации ст. 75,76 и $76^{1}$ УК РФ, в частности, лицо, которое ранее было освобождено от уголовной ответственности [5].

\section{Выводы}

Подводя итог сказанному, сформулируем следующий вывод. Для человека, совершившего преступление, освобождение от уголовной ответственности в той форме, которая определена действующим уголовным законом, является не противоречащим Конституции опровержением презумпции невиновности, а 
последним предоставленным законом шансом сохранить свой юридический статус невиновного лица незыблемым.

Что же касается фактически невиновного лица, то ему, на наш взгляд, предоставлена внушительная гарантия от необоснованного прекращения в отношении его уголовного дела (преследования) по нереабилитирующим основаниям в виде права возражать против принятия подобного решения и настаивать на продолжении производства по делу, обязанности компетентных органов разьяснять содержание данного права обвиняемому или подозреваемому и указания на недопустимость выносить в этом случае решения, посредством которых осуществляется освобождение от уголовной ответственности (ч. 2 ст. 27, ч. 3 и 4 ст. 28 , ч. 4 и 5 ст. $28^{1}$ УПК РФ).

Таким образом, нет никаких оснований признавать институт освобождения от уголовной ответственности и корреспондирующие ему процессуальные нормы противоречащими ст. 49 Конституции РФ.

\section{ПРИМЕЧАНИЕ}

${ }^{1}$ Статья подготовлена при поддержке гранта РГНФ, проект № 16-03-00164.

\section{СПИСОК ЛИТЕРАТУРЫ}

1. Камнев, Р. Г. Специальные основания освобождения от уголовной ответственности, характеризующие обстановку совершения преступления / Р. Г. Камнев, Л. В. Лобанова / науч. ред. Л. В. Лобанова. - Волгоград : Принт, 2009. - 140 с.

2. Карпушин, М. П. Уголовная ответственность и состав преступления / М. П. Карпушин, В. И. Курляндский. - М. : Юридическая литература, 1974. $231 \mathrm{c}$.

3. Кругликов, А. П. Конституционные принципы уголовного процесса и некоторые проблемы прекращения уголовных дел и уголовного преследования / А. П. Кругликов, И. А. Бирюкова // Проблемы освобождения от уголовной ответственности и наказания по законодательству Республики Беларусь, России и Украины: уголовно-правовой и уголовно-процессуальный аспекты / под науч. ред. Л. В. Лобановой, И. С. Дикарева. - Волгоград : Изд-во ВолГУ, 2012. - С. 327-332.

4. Ларин, А. М. Презумпция невиновности / А. М. Ларин. - М. : Наука, 1982. - 152 с.
5. Постановление Пленума Верховного суда РФ «О применении судами законодательства, регламентирующего основания и порядок освобождения от уголовной ответственности» от 27 июля 2013 г. № 19 // Бюллетень Верховного Суда РФ. 2013. - № 8.

6. Проценко, С. В. О противоречии действующего института освобождения от уголовной ответственности основным положениям Конституции РФ / С. В. Проценко // Российский следователь. 2010. - № 19. - С. 22-25.

7. Якуб, М. Л. Освобождение от уголовной ответственности / М. Л. Якуб // Вестник Московского университета. Серия 11, Право.-1981.-№3.-С. 18-26.

\section{REFERENCES}

1. Kamnev R.G., Lobanova L.V. Spetsialnye osnovaniya osvobozhdeniya ot ugolovnoy otvetstvennosti, kharakterizuyushchie obstanovku soversheniya prestupleniya [Special Grounds of the Release from Criminal Liability Described the Crime Situation]. Volgograd, Print Publ., 2009. 140 p.

2. Karpushin M.P., Kurlyandskiy V.I. Ugolovnaya otvetstvennost i sostav prestupleniya [The Criminal Liability and the Crime Components]. Moscow, Yuridicheskaya literatura Publ., 1974. 231 p.

3. Kruglikov A.P., Biryukova I.A. Konstitutsionnye printsipy ugolovnogo protsessa $\mathrm{i}$ nekotorye problemy prekrashcheniya ugolovnykh del i ugolovnogo presledovaniya [Constitutional Principles of the Criminal Procedure and Some Issues of the Termination of Criminal Case]. Lobanova L.V., Dikarev I.S., eds. Problemy osvobozhdeniya ot ugolovnoy otvetstvennosti $i$ nakazaniya po zakonodatelstvu Respubliki Belarus, Rossii $i$ Ukrainy: ugolovno-pravovoy $i$ ugolovnoprotsessualnyy aspekty [Issues of Release from Criminal Liability and Punishment by Reference to the Law of the Republic of Belarus, Russia and Ukraine: Criminal and Criminally-Remedial Aspects]. Volgograd, izd-vo VolGU, 2012, pp. 327-332.

4. Larin A.M. Prezumptsiya nevinovnosti [Presumption of Innocence]. Moscow, Nauka Publ., 1982. $152 \mathrm{p}$.

5. Postanovlenie Plenuma Verkhovnogo suda $\mathrm{RF}$ “O primenenii sudami zakonodatelstva, reglamentiruyushchego osnovaniya i poryadok osvobozhdeniya ot ugolovnoy otvetstvennosti" oт 27.07.2013 № 19 [Resolution of the Plenum of the Supreme Court of the Russian Federation "On the application of the law courts, regulatory grounds and procedures for exemption from criminal liability" of July 27, 2013 no. 19]. Byulleten Verkhovnogo suda $R F, 2013$, no. 8 . 
6. Protsenko S.V. O protivorechii deystvuyushchego instituta osvobozhdeniya ot ugolovnoy otvetstvennosti osnovnym polozheniyam Konstitutsii RF [On the Contradiction of the Current Institute of Release from Criminal Liability to Fundamental Principles of the Constitution of the
Russian Federation]. Rossiyskiy sledovatel, 2010, no. 19 , pp. 22-25.

7. Yakub M.L. Osvobozhdenie ot ugolovnoy otvetstvennosti [Release from Criminal Liability]. Vestnik Moskovskogo universiteta. Seriya 11, Pravo, 1981, no. 3, pp. 18-26.

\section{Information About the Author}

Lyubov V. Lobanova, Doctor of Juridical Sciences, Professor, Head of Department of Criminal Law, Volgograd State University, Prosp. Universitetsky, 100, 400062 Volgograd, Russian Federation, lobanova@volsu.ru,up@volsu.ru.

\section{Информация об авторе}

Любовь Валентиновна Лобанова, доктор юридических наук, профессор, заведующая кафедрой уголовного права, Волгоградский государственный университет, просп. Университетский, 100, 400062 г. Волгоград, Российская Федерация, lobanova@volsu.ru, up@volsu.ru. 